\title{
The Development of Web Based Learning Using Efront at High Class Social Science Subject
}

\author{
Husna Parluhutan Tambunan ${ }^{1 *}$, Risma Sitohang, ${ }^{2}$ Demmu Karokaro ${ }^{3}$, Wesly Silalahi ${ }^{4}$ \\ ${ }^{1-4}$ Universitas Negeri Medan, Indonesia \\ *husnatambunan@gmail.com
}

\begin{abstract}
This study is a research and development with ADDIE model. Researchers conducted interviews with students majoring in Elementary School Teacher (PGSD) to find out the application form required in the course of learning development of web based learning at high class social science subject with blended learning models. Furthermore, researchers designed the initial shape and structure of the application work, and structure develop android apps using android software studio accordance with the application form needed by the students. In the implementation phase the researchers asked two experts are subject matter experts and media experts to assess the applications already developed products. When implementing the researchers also asked students from the Department of Primary School Teacher Education that as many as 30 people to give an assessment of product applications already be. Media experts provide an assessment of 59.40 with an average value of 3.61 and considered good and decent. Media experts give a value of 75.00 with an average of 3.40 were categorized as feasible. For the material, the researchers asked the expert appraisal that truly understands even mastered the course at high class social science subject. Media experts provide an assessment of 59.40 with an average value of 3.61 and considered good and decent.
\end{abstract}

Keywords: web based learning, effort, social science subject

\section{Introduction}

Education is a human effort to grow and develop the potential of both physical and spiritual traits in accordance with the values that exist in society and culture [1]. So that the progress of a nation cannot be separated from the educator factor, because education has an important role in efforts to increase human resources which is an important element in the development of a nation. Based on RI Law No.20/2003 (Chapter 1) concerning the Education system National defines. Education is a conscious and planned effort to create an atmosphere of learning and learning process so that students actively develop their potential to have spiritual strength, self-control, personality, intelligence, noble character and skills needed by themselves, society, nation and state [2].

Based on this law, education has a very important role to guarantee the development and continuity of the life of the nation because education is a process in an effort to form intelligent and skilled people, to realize qualified and creative human resources and be able to compete in facing challenges and advances in science and technology. The development of Information and Communication Technology (ICT) currently has led the world to the supply of information sources that are very numerous and widespread with relative time brief [3]. This technology is a network technology that connects computers around the world, so that the computers can communicate with each other. This technology is known by the name of the 
internet. Information that is spread on the internet comes from individuals and institutions that are intentionally published so that the wider community can access it relatively quickly.

The influence of internet technology has entered almost all fields of human life: political, economic, social, and education. The use of the internet in education has gained popularity after the concept of e-learning. Wahono and Romi Satria [3] in their article entitled "eLearning System Based on Community Motivation Models" in the Technical Journal states that e-learning will bring the effect of the transformation of conventional education into digital form, both in content and the system. This transformation is also related to the weaknesses of conventional learning systems that are less flexible in accommodating the rapid development of science and technology compared to the development of teaching abilities. In addition, elearning can be used as an alternative solution to overcome boring classical learning problems and less able to condition individual learning of students [4]. Therefore, the author feels interested in discussing the concept and implementation of web based learning in high class social sciences courses as one form of e-learning that is starting to be intensively practiced in various countries and especially in Indonesia which is currently facing the industrial revolution 4.0.

\section{Research Method}

This research uses research and development methods using ADDIE model [5] which consists of five phases (Analysis, Design, Development, Implementation, and Evaluation). The ADDIE model uses several steps as shown in Figure below.

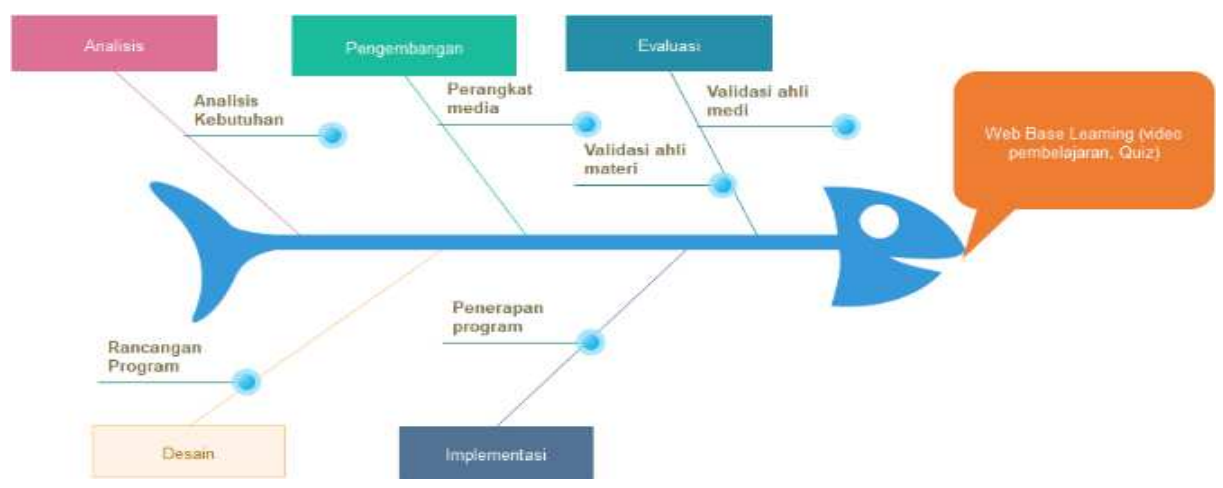

Figure 1. ADDIE Model

Data collection techniques in this study were observation, interviews, and questionnaires or questionnaires. Observations were used to see how students' responses to web-based learning were developed. Interviews were to complete the data obtained from questionnaires. While the questionnaire is used to capture data validation experts media and content as well as display and programming experts about the product developed by looking at aspects of evaluation and display as well as responses regarding the practicality of the product.

\section{Results and Discussion}

Based on the process of implementing development research, the results of the research are carried out in the following way. This research stage uses the stages of ADDIE 
development, namely Analysis, Design, Development, Implementation (limited trial) and Evaluation.The development of Web Based Learning begins with analyzing some of the requirements needed. These needs include: material selection, user determination, eligibility criteria, and software for developing android applications learning models of blended learning.

Content or web-based courses in this case are high class course learning materials based on Semester Lecture Design (RPS) issued by the team presented in the mobile learning application developed are : (1) Characteristics, events, facts, concepts and generalizations of social sciences in elementary school curriculum, (2) Social studies learning in the era of globalization and cultural diversity, (3) Problem based learning, (4) Constructivism learning approach, (5) Inquiry approach in social studies, (6) Integrated social science, (7) Understanding learning media, and (8) Assessment, evaluation sheet and evaluation sheet.

Phase of implementation, researchers create a learning scenario with the blended learning model, and consists of 4 meetings namely face-to-face meetings and online meetings using the android application for high class social science lectures. When testing researchers asked two experts, namely media experts and material experts to provide an assessment of the application product [6].

Media experts are respondents who are considered to have good and bad assessments of a learning media. This application is tested by one person who assesses the media that plays a role in assessing the engineering side of software and visual communication [7]. The results of the media assessment recap are shown in Table below:

Tabel 1. Scoring Data Item Feasibility of Media

\begin{tabular}{clc}
\hline No & \multicolumn{1}{c}{ Item } & Skor \\
\hline 1 & Description clear application & 3,00 \\
2 & The application installation process goes well & 3,50 \\
3 & Free use of the application is easy to understand & 3,50 \\
4 & Application does not take up much memory & 3,50 \\
5 & The process of loading media goes well & 3,50 \\
6 & Display layout interesting applications & 3,00 \\
7 & The composition and interesting colors used design & 3,00 \\
8 & Display design, size and layout of the proper icon & 3,00 \\
9 & Icon / button that allows users to use the media & 3,50 \\
10 & Audio files in the app runs fine & 3,50 \\
11 & The video link learning goes well & 3,50 \\
12 & Applications can be run in all versions of android & 3,50 \\
13 & Use of the font type and size are correct & 3,50 \\
14 & The use and effect of the application interface is simple and attractive & 3,50 \\
15 & bug or error in the application a little & 3,50 \\
16 & Application can be easily modified & 3,00 \\
17 & Applications can be used anytime and anywhere & 3,50 \\
18 & Some or all of the application programs can be recovered & 3,50 \\
19 & Design of a display according to the user level & 3,50 \\
20 & The ease and simplicity in pengoprasian & 3,50 \\
21 & Applications can be run disemuai screen resolution & 3,50 \\
22 & Master application easily transferred from one phone to another phone. & 3,00 \\
\hline Total & & 75,00 \\
\hline Average & & 3,40 \\
\hline Criteria & & Very Decent \\
\hline & & \\
\hline
\end{tabular}




\section{Results of Expert Material Assessment}

Content or material experts are respondents who assess the feasibility of learning design aspects and learning material content. In this study the material experts determined by the authors are experts who truly understand how interesting learning designs are based on the material and sub-material in the Social Sciences high class course and have a very relevant background in social science. The results of the material assessment are shown in Table 2.

Tabel 2. Scoring Data Item Feasibility of Material Assessment

\begin{tabular}{|c|c|c|}
\hline No. & Item & Score \\
\hline 1 & $\begin{array}{l}\text { The material contained in the application in } \\
\text { accordance with the curriculum KKNI }\end{array}$ & 4.00 \\
\hline 2 & $\begin{array}{l}\text { This application can support the achievement of } \\
\text { learning goals }\end{array}$ & 4.00 \\
\hline 3 & $\begin{array}{l}\text { This application can support the implementation of } \\
\text { blended learning models }\end{array}$ & 4.00 \\
\hline 4 & $\begin{array}{l}\text { This application can make learners interested to } \\
\text { learn more about the teaching materials }\end{array}$ & 3.50 \\
\hline 5 & $\begin{array}{l}\text { The material contained in the application in } \\
\text { accordance with the RPS course Development of } \\
\text { Students. }\end{array}$ & 4.00 \\
\hline 6 & Applications can broaden learners & 3.50 \\
\hline 7 & $\begin{array}{l}\text { This application allows students to learn } \\
\text { independently }\end{array}$ & 4.00 \\
\hline 8 & Readability clear sentences and paragraphs & 3.50 \\
\hline 9 & $\begin{array}{l}\text { The material contained in the application are } \\
\text { arranged in a systematic and coherent }\end{array}$ & 3.00 \\
\hline 10 & $\begin{array}{l}\text { displayed in the application can help learners to } \\
\text { understand the material }\end{array}$ & 4.00 \\
\hline 11 & $\begin{array}{l}\text { The video link is presented in accordance with the } \\
\text { material }\end{array}$ & 3.50 \\
\hline 12 & Encouraging learners actively involved & 4.00 \\
\hline 13 & $\begin{array}{l}\text { Exercises given in the application is in conformity } \\
\text { with the material presented }\end{array}$ & 3.50 \\
\hline 14 & Suitability exercises with less learning objectives & 4.00 \\
\hline 15 & Uses terms that are easily understood & 3.50 \\
\hline 16 & $\begin{array}{l}\text { Provide motivation / interest and curiosity of } \\
\text { learners }\end{array}$ & 3.50 \\
\hline \multicolumn{2}{|c|}{ Total number } & 59.40 \\
\hline \multicolumn{2}{|c|}{ Average } & 3.61 \\
\hline \multicolumn{2}{|c|}{ Criteria } & very Decent \\
\hline
\end{tabular}

\section{Conclusion}

Based on the results of web-based learning development using efront in high class social Sciences courses it can be concluded that will be used in PGSD students on semester $5^{\text {th }}$ ready to be used in the learning process activities. Web based learning social science contains 
material, learning videos, quiz tests, and virtual classroom. This web based learning is prepared based on the results of expert assessments that are worth mentioning to be used in PGSD for students on semester $5^{\text {th }}$ at Universitas Negeri Medan.

\section{References}

[1] Ikhsan. (2003), Dasar-Dasar Kependidikan, Penerbit : Rieka Cipta.

[2] UU RI No.20 Tahun 2003, tentang Sistem Pendidikan Nasional.

[3] Satria, Wahono. (2007), Sistem e-Learning Berbasis Moodle.

[4] Arsyad Azhar. (2011), Media Pembelajaran. Jakarta: PT Raja Grafindo Persada.

[5] Pribadi, B. A. (2009), Langkah penting merancang kegiatan pembelajaran yang efektif dan berkualitas. In Model Desain Sistem Pembelajaran. Jakarta: Dian Rakyat.

[6] Hardianto, Deni. (2005). Media Pendidikan sebagai Sarana Pembelajaran yang Efektif. Majalah Ilmiah Pembelajaran, 1(1), pp. 95-104.

[7] Huda, Arif Akbarul. (2013), Live Coding! 9 Aplikasi Buatan Sendiri. Yogyakarta: ANDI. 